\title{
TITIK SINGGUNG KERAGAMAN SISTEM HUKUM DALAM PEMBAGIAN HARTA KEKAYAAN PERKAWINAN PADA PERKAWINAN SERIAL
}

\author{
Yunanto \\ Fakultas Hukum Universitas Diponegoro \\ Jl. Prof. Soedarto, S.H., Tembalang, Semarang \\ yun_yunanto@yahoo.com
}

\begin{abstract}
Reality shows inconsistencies in interpreting and sharing marital assets due to a variety of rules, especially in serial marriage. The formulation of the problem in this study relates to the point of reference in the similarity of the meaning and nature of the distribution of marital assets in the diversity of the legal system of marriage assets; and the completion of the distribution of marital assets in serial marriage based on a variety of rules in practice in court. The approach method used in this study is an empirical juridical method. The results of the study show: there are similarities in the meaning and nature of the distribution of marital assets in the diversity of the legal system of marital wealth in assets acquired during marriage outside of assets acquired due to inheritance and grants; and in a serial marriage each group of separate and independent marriages is formed.
\end{abstract}

\begin{abstract}
Abstrak
Realitas menunjukkan adanya inkonsistensi dalam memaknai dan melakukan pembagian harta kekayaan perkawinan akibat adanya keragaman aturan khususnya dalam perkawinan serial. Rumusan masalah dalam penelitian ini terkait titik singgung kesamaan makna dan hakikat pembagian harta kekayaan perkawinan dalam keragaman sistem hukum harta perkawinan; dan penyelesaian pembagian harta kekayaan perkawinan dalam perkawinan serial berbasis keragaman aturan dalam praktik di pengadilan. Metode pendekatan yang digunakan dalam penelitian ini adalah metode yuridis empiris. Hasil penelitian menunjukkan: terdapat kesamaan makna dan hakikat pembagian harta kekayaan perkawinan dalam keragaman sistem hukum harta kekayaan perkawinan pada harta yang diperoleh selama perkawinan di luar harta yang diperoleh karena warisan dan hibah; dan dalam perkawinan serial terbentuk masing-masing kelompok harta kekayaan perkawinan yang terpisah dan berdiri sendiri-sendiri.
\end{abstract}

Kata Kunci : harta perkawinan, perkawinan serial, keragaman aturan.

\section{A. Pendahuluan}

Indonesia adalah negara yang majemuk, termasuk kemajemukan dalam sistem hukum yang berlaku di masyarakat. Realitas adanya pluralitas tersebut kemudian sering dimaknai bertentangan dengan ideologi sentralisme hukum. Ideologi sentralisme hukum (legal centralism) diartikan sebagai suatu ideologi yang menghendaki pemberlakuan hukum negara (state law) sebagai satu satunya hukum yang mengikat semua warga masyarakat. (Tanya, 2011) 
Di Indonesia ketentuan tentang perkawinan diatur dalam UU No. 1 tahun 1974 tentang Perkawinan dan PP No. 9 tahun 1975 yang merupakan hukum materiil perkawinan. (Sirajudin, 2015) Dalam konteks hukum harta kekayaan perkawinan, kemajemukan bidang hukum tersebut terpancar dalam berbagai peraturan yang masih berlaku sampai saat ini, seperti dalam hukum adat, Kompilasi Hukum Islam, KUH.Perdata, dan UU No. 1 tahun 1974 tentang Perkawinan (UUP) sebagai hukum positif. Dalam hukum adatpun antara daerah yang satu dengan yang lainnya juga masih terdapat pluralitas hukum, yang didasarkan pada garis patrilineal, matrilineal dan parental.

Dalam praktik, persoalan terkait dengan harta kekayaan suami istri tidak hanya terjadi akibat adanya pluralitas aturan hukum harta kekayaan perkawinan tersebut yang menyebabkan terjadinya inkonsistensi dalam penerapan hukumnya. Juga, terdapatnya percampuran harta kekayaan ke dalam perkawinan lain akibat adanya perkawinan lebih dari satu kali (perkawinan serial), yang membawa kesulitan didalam memaknai dan melakukan pembagian harta tersebut.

Sebenarnya undang-undang telah memberikan jalan keluar dengan memberi kebebasan pada calon suami istri untuk mengatur harta kekayaan perkawinan mereka sendiri atas dasar kesepakatan dengan menyimpangi ketentuan undang-undang. Instrumen hukum yang digunakan adalah dengan membuat perjanjian kawin. Dengan perjanjian kawin ini bisa disepakati adanya pemisahan harta, yang berarti persatuan ditiadakan sama sekali (algehele uitsluiting van de gemeenschap); atau dengan persatuan terbatas, yang bisa berupa persatuan untung dan rugi (gemeenschap van winst enverlies), dan persatuan hasil dan pendapatan (gemeenschap van vruchten en inkomsten), atau bentuk-bentuk lainnya yang dlandasi oleh kesepakatan calon suami istri.

Hanya saja, pembuatan perjanjian kawin dalam praktik belum terlalu membudaya di masyarakat dengan berbagai alasan di antaranya hal tersebut merupakan hal yang masih tabu untuk dilakukan. Pada hal pembuatan perjanjian kawin merupakan hal yang relaitas yang bisa meredam konflik sengketa pembagian harta kekayaan perkawinan jika kemudian perkawinan putus terutama karena perceraian. Selain itu adanya perjanjian kawin juga tidak menghilangkan hak-hak untuk mewaris. Artinya, perjanjian kawin ini hanya berdaya guna ketika perkawinan putus karena perceraian. Jika perkawinan berjalan selamanya dan berakhir karena kematian, perjanjian kawin tidak terlalu berdaya guna.

Pengaturan bidang perkawinan dan khususnya bidang harta kekayaan perkawinan dalam perundang-undangan berarti peraturan tersebut ditanggapi sebagai 
norma yang berlaku secara yuridis. Memahami hukum sebagai norma berarti juga memahami hukum sebagai sesuatu yang seharusnya (das sollen). Memahami hukum sebagai das sollen berarti juga menginsyafi bahwa hukum merupakan bagian dari kehidupan kita yang berfungsi sebagai pedoman yang harus diikuti dengan maksud supaya kehidupan kita diatur sedemikian rupa sehingga hak-hak dan kewajiban orang dibagi sebagaimana mestinya. (Anshori, 2006)

Jika sudah bicara tentang hukum sebagai suatu sistem norma, Hans Kelsen dengan Stufenbau theorie-nya berpendapat bahwa suatu norma dibuat menurut norma yang lebih tinggi, dan norma yang lebih tinggi ini pun dibuat menurut norma yang lebih tinggi lagi, dan demikian seterusnya sampai kita berhenti pada norma yang tertinggi yang tidak dibuat oleh norma lagi melainkan ditetapkan terlebih dahulu keberadaannya oleh masyarakat atau rakyat, yang disebut sebagai Grundnorm atau Basic Norm (norma dasar), dan Grundnorm pada dasarnya tidak berubah-ubah. (Pudjirahayu, 2005)

Dengan terbitnya UUP diharapkan akan terjadi perubahan dalam masyarakat, di mana masyarakat diharapkan bertindak sesuai dengan apa yang dikehendaki dalam ketentuan UUP. Hal ini karena UUP sebagai norma hukum dalam pembentukannya juga telah memperhatikan dan mengadopsi berbagai kepentingan golongan msyarakat, yang bersumber dari berbagai sistem hukum yang selama ini berlaku.

Namun apa yang dikehendaki dengan diundangkannya UUP tersebut dalam implementasinya tidak selalu sinergis dengan tujuannya. Apa yang diharapkan tidak sejalan dengan praktiknya, yang oleh Seidman banyak faktor yang meliputi kekuatan personal dan sosial yang mempengaruhi bekerjanya hukum. Dalam tataran empiris, implementasi hukum harta kekayaan perkawinan, tidak hanya berupa upaya menerapkan unifikasi hukum dalam realitas kemajemukan hukum, namun juga bagaimana menciptakan keadilan dalam pembagian harta kekayaan perkawinan terutama dalam perkawinan serial.

Adanya problem dalam penerapan hukum harta kekayaan perkawinan dalam realitas kemajemukan membawa pemikiran bagaimana mewujudkan aturan yang baku sebagai pedoman dalam menyelesaikan sengketa harta kekayaan perkawinan dengan mengoptimalkan ketentuan-ketentuan yang telah ada dalam berbagai sistem hukum. Untuk itu, adanya keragaman sistem hukum harta perkawinan tersebut selain yang pasti tentu terdapat perbedaan antara ketentuan satu sistem dengan sistem hukum lainnya bahkan mungkin bertentangan, perlu dicari titik singgung kesamaan di antara mereka yang kiranya bisa menjadi dasar pembentukan hukum harta kekayaan 
perkawinan yang berlaku bagi seluruh warga masyarakat.

Atas dasar apa yang diuraikan tersebut, permasalahan yang dapat diangkat dalam tulisan ini adalah :

1. Adakah titik singgung kesamaan makna dan hakikat pembagian harta kekayaan perkawinan dalam keragaman sistem hukum harta kekayaan?

2. Bagaimana penyelesaian pembagian harta kekayaan perkawinan dalam perkawinan serial berbasis keragaman aturan dalam praktik di pengadilan?

Rumusan permasalahan tersebut akan penulis jabarkan dalam metode yuridis empiris, yaitu suatu pendekatan masalah dengan cara meninjau peraturan-peraturan yang telah diberlakukan dalam masyarakat sebagai hukum positif dengan peraturan pelaksanaannya termasuk implementasinya di lapangan. Paradigma pemikiran yang digunakan adalah paradigma konstruktivisme atau lebih tepatnya pada aliran legal contructivism. Dalam konstruktivisme realitas bisa dipahamai dalam bentuk kontruksi mental yang bermacam-macam dan tak dapat diindra, yang didasarkan secara sosial dan pengalaman, berciri lokal dan spesifik dan bentuk serta isinya bergantung pada manusia atau kelompok individual yang memiliki kontstruksi tersebut. (Guba \& Lincoln, 2009)

\section{B. Pembahasan}

1. Titik Singgung Kesamaan Makna dan Hakikat Pembagian Harta dalam Keragaman Sistem Hukum Harta Kekayaan Perkawinan

Dalam UUP harta benda dalam perkawinan atau lazim disebut harta kekayaan perkawinan diatur pasal 35 sampai dengan 37. Namun tidak diatur lebih lanjut dalam peraturan pelaksanaannya (PP No. 9 tahun 1975). Ketentuan hukum harta kekayaan perkawinan sebelum UUP adalah : KUH.Perdata, Hukum Islam dan Hukum Adat. Jadi, ada hukum positif (UUP) di satu sisi, dan hukum lama di sisi lain.

Jika suatu ketentuan dalam UUP dinyatakan belum berlaku efektif, dapat diterapkan ketentuan lama dengan dasar Pasal 66 UUP, yang menjelaskan :

"Untuk perkawinan dan segala sesuatu yang berhubungan dengan perkawinan berdasarkan atas undang-undang ini, maka dengan berlakunya undang-undang ini ketentuan ketentuan yang diatur dalam Kitab Undang Undang Hukum Perdata (Burgerlijk Wetboek), Ordonansi Perkawinan Indonesia Kristen (Huwelijks Ordonantie Christen Indonesiers S. 1933 No. 74), Peraturan Perkawinan Campuran (Regeling op de Gemengde Huwelijken S.1898 No. 158), dan peraturan-peraturan lain yang mengatur tentang perkawinan sejauh telah diatur dalam undang-undang ini , dinyatakan tidak berlaku”. 
Ketentuan demikian dipertegas dengan Surat MA tertanggal 20 Agustus 1975 No. MA/Pemb/0807/75 tentang Petunjuk petunjuk MA mengenai Pelaksanaan UU No. 1 tahun 1974 dan PP No. 9 tahun 1975.(Satrio, 1991) Dalam Surat Edaran MA tersebut di antaranya menyebutkan (dalam sub 4) "bahwa .... tentang Harta Benda Perkawinan..... ternyata tidak diatur dalam PP karenanya belum dapat diperlakukan secara efektif dan dengan sendirinya untuk hal-hal itu masih diperlakukan ketentuanketentuan hukum dan perundang-undangan lama.

Dalam menyikapi Surat Edaran MA tersebut kemudian muncul Putusan MA No. 726 K/Sip/1976 tanggal 15 Februari 1977, yang masih menggunakan dasar hukum lama dalam menyelesaikan sengketa yang para pihaknya tunduk pada KUH.Perdata. Selain itu ada juga yang menafsirkan bahwa ketentuan harta kekayaan perkawinan dalam UUP sudah berlaku dengan menggunakan peraturan lama sebagai peraturan pelaksanaannya.

Pada akhirnya dalam praktik ditemukan inkonsistensi dalam penerapan aturan hukum untuk menyelesaikan sengketa harta kekayaan perkawinan yang tercermin dari karagaman penggunaan dasar hukum di antara UUP, KUH.Perdata, Kompilasi Hukum Islam (KHI) dan hukum adat. Di antara keragaman sistem hukum tersebut tentu terdapat perbedaan dan kesamaan makna dan hakikat dalam pembagian harta kekayaan perkawinan termasuk dalam perkawinan serial.

Pengertian harta kekayaan menurut UUP dapat dilihat dalam Pasal 35 menyatakan :

(1). Harta benda yang diperoleh selama perkawinan menjadi harta bersama.

(2). Harta bawaan dari masing-masing suami dan isteri dan harta benda yang diperoleh masing-masing sebagai hadiah atau warisan, adalah dibawah penguasaan masing-masing sepanjang para pihak tidak menentukan lain. Ketentuan di dalam UUP menyatakan bahwa harta yang diperoleh dalam perkawinan akan menjadi harta bersama, harta yang diperoleh sebelum perkawinan menjadi harta asal. (Judiasih, 2018) Dari apa yang ditentukan dalam pasal tersebut, bisa disimpulkan bahwa UUP membedakan kelompok harta perkawinan menjadi kelompok "harta bersama" dan kelompok "harta pribadi". Penggunaan istilah "harta bersama dalam UUP ditujukan untuk menyamakan istilah yang beragam yang terdapat dalam hukum adat di berbagai wilayah Indonesia, seperti : harta gono gini (Jawa), harta seharkat (masyarakat Aceh), harta suarang (Minangkabau), harta syarikat (suku melayu), harta guna kaya (Sunda), barang perpantangan (Kalimantan), dan druwe gabro (Bali). 
Namun demikian, apabila melihat dalam praktik masih terlihat penggunaan beragam istilah tersebut. Misalnya pengadilan yang berada di daerah Jawa Madura masih lebih suka mempergunakan istilah "harta gono gini", dan pengadilan yang berada di daerah Aceh masih tetap dipengaruhi istilah hukum adat masyarakat, yaitu istilah "harta seharkat".(Harahap, 1997) Penggunaan istilah yang berasal dari lingkungan adat menunjukkan bahwa dalam realitasnya hukum harta kekayaan perkawinan masih menunjukkan kemajemukan hukum.

Ketentuan pasal 35 (1) UUP yang mengatur tentang harta benda yang diperoleh selama perkawinan menjadi harta bersama (suami isteri), lebih didasarkan pada pengaturan harta kekayaan perkawinan dalam masyarakat parental, sehingga dapat disimpulkan bahwa konsep harta bersama dalam UUP mengambil oper konsep harta benda perkawinan dari hukum adat yang sifatnya parental. Ketentuan demikian berbeda dengan pengaturan dalam masyarakat yang menggunakan sistem kekeluargaan matrilineal, atau patrilineal.

Dalam konsepsi hukum adat tentang harta bersama yang ada di nusantara ini banyak ditemukan prinsip bahwa masingmasing suami isteri berhak menguasai harta bendanya sendiri dan ini berlaku sebagaimana sebelum mereka menjadi suami isteri. Hanya saja apabila ditinjau dari pendekatan filosofis, dimana perkawinan tidak lain dari ikatan lahir bathin di antara suami isteri guna mewujudkan rumah tangga yang kekal dan penuh dalam suasana kerukunan, maka hukum adat yang mengharapkan komunikasi yang terbuka dalam pengelolaan dan penguasaan harta pribadi tersebut, sangat perlu dikembangkan sikap saling menghormati, saling membantu, saling bekerjasama, dan saling bergantung. Dengan demikian keabsahan menguasai harta pribadi masing-masing pihak itu jangan sampai merusak tatanan kedudukan suami sebagai kepala keluarga dan isteri sebagai ibu rumah tangga. (Manan, 2006)

Terbentuknya kelompok harta bersama dalam perkawinan adalah sejak saat tanggal terjadinya perkawinan sampai ikatan perkawinan itu bubar. Penegasan seperti itu nampak pada putusan MA tgl 9 November 1976 No. 1448 K/Sip/1974. Dalam putusan itu ditegaskan : "Sejak berlakunya UU No. 1 tahun 1974, harta benda yang diperoleh selama perkawinan menjadi harta bersama, sehingga pada saat terjadinya perceraian harta bersama tersebut dibagi sama rata antara bekas suami dan isteri". Jadi, patokan untuk menentukan apakah suatu barang atau harta termasuk atau tidak dalam kelompok harta bersama suami istri, ditentukan oleh faktor 'waktu' selama perkawinan antara suami isteri berlangsung, dengan sendirinya harta tersebut menjadi harta bersama. Pengecualiannya : Jika harta yang diperoleh 
berupa warisan atau hibah, maka harta tersebut tidak masuk harta bersama, tetapi merupakan harta pribadi si penerima.

Dengan demikian yang dimaksud dengan harta bersama adalah harta yang diperoleh sepanjang perkawinan baik yang diperoleh suami atau isteri, dan tidak dipersoalkan harta tersebut diatasnamakan sisuami atau isteri. Untuk kepentingan pembuktian di pengadilan apakah suatu harta termasuk harta bersama atau bukan cukup dengan menunjukkan tanggal perkawinan dan tanggal perolehan harta, kecuali harta tersebut diperoleh secara cuma-cuma seperti karena hibah, warisan atau hadiah, maka harta ini termasuk harta pribadi. Selain itu hasil yang diperoleh dari harta pribadi juga masuk menjadi harta bersama. Hal ini didasarkan pada prinsip dari fungsi harta pribadi dalam perkawinan adalah ikut menopang dan meningkatkan kesejahteraan keluarga. Sekalipun hak dan kepemilikan harta pribadi mutlak berada di bawah kekuasaan pemiliknya, namun harta pribadi tidak terlepas fungsinya dari kepentingan keluarga. Barang pokoknya memang tidak boleh diganggu gugat. Hal itu sepanjang tidak ditentukan dalam perjanjian kawin.

Jadi komponen harta bersama terdiri dari:

a. Harta yang diperoleh/dibeli oleh suami sepanjang perkawinan b. Harta yang diperoleh/dibeli oleh isteri sepanjang perkawinan, dan

c. Hasil dari harta pribadi baik milik suami atau isteri.

Sedangkan harta yang dimilki suami atau isteri sebelum perkawinan, dan harta yang diperoleh suami atau isteri karena warisan atau hibah sepanjang perkawinan, menjadi harta pribadi masing-masing (Pasal 35 ayat 2 UUP). Jadi komponen harta pribadi terdiri dari : harta bawaan (harta yang ada sebelum perkawinan), dan harta dari hibah atau warisan (diperoleh setelah perkawinan).

Dari ketentuan tersebut, terlihat adanya perlindungan hukum secara otomatis terhadap harta pribadi. Dalam konteks demikian, apabila suatu perkawinan tidak dibuat perjanjian kawin, maka dalam perkawinan tersebut bisa terdiri dari tiga komponen harta, yakni : harta bersama suami isteri, harta pribadi suami, dan harta pribadi isteri. Dalam hal posisi harta pada saat perkawinan dilangsungkan, menurut UUP selalu dalam posisi nol (posisi tidak ada harta). Selain itu, ada pengaruh terhadap usaha dari orang tua dalam kaitannya dengan pemberian aset (harta kekayaan) terhadap anak-anaknya. (Fafchamps \& Quisumbing, 2005) 
Tabel 1.

\section{Persamaan dan Perbedaan Harta Dalam Perkawinan}

\begin{tabular}{|c|c|c|c|c|}
\hline No & Jenis Harta & $\begin{array}{l}\text { Hukum } \\
\text { (parental) }\end{array}$ & UUP & KUH.Perdata \\
\hline \multirow[t]{3}{*}{1} & Harta Bawaan : & & & \\
\hline & Harta Bawaan Suami & Harta gono suami & Harta pribadi suami & Harta Persatuan \\
\hline & Harta Bawaan isteri & Harta gini isteri & Harta pribadi isteri & Harta persatuan \\
\hline \multirow[t]{3}{*}{2} & Hutang Bawaan : & & & \\
\hline & Hutang bawaan suami & Beban pribadi suami & Beban pribadi suami & Beban persatuan \\
\hline & Hutang bawaan isteri & Beban pribadi isteri & Beban pribadi suami & Beban persatuan \\
\hline \multirow[t]{3}{*}{3} & Harta Cuma-Cuma : & & & \\
\hline & $\begin{array}{l}\text { Warisan/hibah yang } \\
\text { diterima suami }\end{array}$ & Harta pribadi suami & Harta pribadi suami & Harta persatuan \\
\hline & $\begin{array}{l}\text { Warisan/hibah yang } \\
\text { diterima isteri }\end{array}$ & Harta pribadi isteri & Harta pribadi isteri & Harta persatuan \\
\hline \multirow[t]{5}{*}{4} & Harta Perolehan atau & & & \\
\hline & Pembelian selama & & & \\
\hline & Perkawinan : & & & \\
\hline & Pembelian suami & $\begin{array}{l}\text { Harta gono gini (harta } \\
\text { bersama) }\end{array}$ & Harta bersama & Harta persatuan \\
\hline & Pembelian isteri & $\begin{array}{l}\text { Harta gono gini (harta } \\
\text { bersama) }\end{array}$ & Harta bersama & Harta persatuan \\
\hline \multirow[t]{4}{*}{5} & Hutang / kerugian yang & & & \\
\hline & $\begin{array}{ll}\text { Dibuat } & \text { selama } \\
\text { perkawinan : } & \end{array}$ & & & \\
\hline & Yang dibuat suami & Beban bersama & Beban bersama & Beban persatuan \\
\hline & Yang dibuat isteri & Beban bersama & Beban bersama & Beban persatuan \\
\hline
\end{tabular}

Dari tabel di atas bisa diketahui, jika menyangkut harta yang diperoleh selama perkawinan dan hutang atau kerugian yang terjadi selama perkawinan, ketiga aturan menunjukkan kesamaan. Perbedaannya, menyangkut harta bawaan dan harta yang diperoleh karena hibah dan warisan. Sedangkan semua yang ada dalam tabel tersebut yang terkait dengan hukum adat (parental) dan UUP adalah sama, karena UUP mengambil oper konsep hukum adat.

Dengan demikian, untuk semua harta yang diperoleh selama perkawinan yang tidak terkait dengan harta yang diperoleh secara cuma-cuma baik berupa hibah ataupun warisan, dari keragaman sitem hukum harta kekayaan memiliki konsep makna dan pembagian yang sama. Artinya, jika menyangkut harta tersebut, apapun hukumnya dan dari golongan manapun para pihaknya, penerapan ketiga aturan tersebut tidak membawa persoalan, karena terdapat kesamaan.

\section{Penyelesaian Pembagian Harta Kekayaan Perkawinan Dalam Perkawinan Serial Berbasis}




\section{Keragaman Aturan Dalam Praktik di Pengadilan}

Perkawinan dapat putus di antarnya karena kematian dan perceraian. Putusnya perkawinan akan membawa akibat hukum. Dampak perceraian bisa terjadi pada pendapatan rumah tangga setelah beberapa waktu perceraian. (de Vaus, Gray, Qu, \& Stanton, 2014) Dalam memutuskan perkara pembagian harta kekayaan perkawinan, hakim dituntut untuk menyelesaikan pembagian secara adil. Untuk mewujudkan keadilan dalam putusan bagi para pihak tentu tidak mudah, karena keadilan bagi satu pihak bisa dirasakan tidak adil bagi pihak lain. Keadilan memang merupakan salah satu tujuan hukum, selain kepastian dan kemanfaatan.

Sebagaimana prinsip tiga nilai dasar yang harus diwujudkan dalam penerapan hukum oleh Gustav Radbruch, yakni : nilai keadilan, kepastian hukum dan kemanfaatan. Dalam teori Radbruch, keadilan sebagai core dari tata hukum. Tujuan Radbrbruch dengan proposal keadilannya itu adalah untuk menjamin agar tata hukum benar-benar berfungsi sebagai penjamin kehidupan dan martabat manusia. Keadilan menjadi landasan moral dan sekaligus tolok ukur sistem hukum positif. Kepada keadilan hukum positif berpangkal. Keadilan juga bersifat konstitutif, karena keadilan harus menjadi unsur mutlak bagi hukum sebagai hukum. Tanpa keadilan, sebuah aturan tidak pantas menjadi hukum. (Tanya, 2011)

Untuk menghadapi dilema karena tidak bisa mewujudkan tiga nilai dasar hukum dari Gustav Radbruch, yakni keadilan, kepastian dan kemanfaatan sebagai satu kesatuan, maka penggunaan tiga nilai dasar tujuan hukum tersebut harus menggunakan asas prioritas. Prioritas pertama keadilan, baru kemanfaatan kemudian kepastian.(Riyanto, 2009) Idealnya, hukum memang harus mengakomodasikan ketiganya. Putusan hakim, semestinya merupakan resultante dari ketiganya, meskipun itu sulit diwujudkan karena untuk mewujudkan salah satunya terkadang harus meminggirkan tujuan yang lainnya.

Muara semua itu adalah mewujudkan keadilan substantial. Pada judul kepala putusan yang berbunyi : "Demi Keadilan Berdasarkan Ketuhanan Yang Maha Esa”, secara tersirat dapat dijadikan landasan untuk mewujudkan keadilan substansial. Selain itu juga terdapat pedoman yang diberikan Mahkamah Agung RI, bahwa putusan hakim harus mempertimbangkan segala aspek yang bersifat yuridis, filosofis, dan sosiologis, sehingga keadilan yang ingin dicapai, diwujudkan, dan dipertanggungjawabkan dalam putusan hakim adalah keadilan yang berorientasi pada keadilan hukum (legal justice), keadilan moral (moral justice), dan keadilan masyarakat (sosial justice). (Rifai, 
2010) Namun kedua hal tersebut sering terabaikan, untuk mengejar keadilan formal.

Dengan demikian peluang untuk menegakkan keadilan substantif dalam praktik di pengadilan masih sulit diwujudkan, karena umumnya hakim masih memegang tradisi yang kuat dengan melandaskan pada paradigma positivisme yang menekankan pada prosedur dan memandang hukum sebatas aturan belaka, sehingga yang terwujud adalah keadilan prosedural, bukan keadilan substansial.

Secara normatif keadilan formal yang terwujud dalam pembagian harta kekayaan perkawinan adalah apabila telah dilakukan pembagian secara seimbang masing-masing suami istri mendapatkan bagian setengah bagian. Dasar pembagian demikian adalah asas keseimbangan kedudukan suami istri; Pasal 128 KUH.Perdata; dan yurisprudensi sebagaimana putusan Mahkamah Agung tertanggal 9 November 1976 No. 1448 K/Sip/1974 yang menyatakan harta benda yang diperoleh selama perkawinan menjadi harta bersama, sehingga pada saat terjadinya perceraian harta bersama tersebut dibagi sama rata antara bekas suami isteri.

Pada hal, pembagian demikian belum tentu mencerminkan keadilan yang sebenarnya, kalau ternyata harta kekayaan perkawinan yang menjadi obyek sengketa walaupun terbukti secara formal tetapi secara materiil sebenarnya merupakan harta pribadi. Oleh karena itu penegakan asas keseimbangan atau asas equalitas dalam pembagian harta kekayaan perkawinan harus diikuti dengan pembagian secara proporsional, demi terwujudnya keadilan substansial. Pembagian proporsional ini tidak harus dalam proporsi $1 / 2: 1 / 2$, tetapi bisa $1 / 3$ $: 2 / 3$, atau $1 / 4: 3 / 4$ dan sebagainya.

Ada sifat khas apabila membicarakan harta kekayaan perkawinan. Hal ini tidak lepas dari sifat harta kekayaan perkawinan sebagai "milik bersama terikat" (gebonden mede eigendom), yaitu suatu bentuk milik bersama dimana suami isteri secara bersamasama menjadi pemilik dari harta persatuan perkawinan. Dengan sifat demikian, maka masing-masing suami isteri tidak dapat menuntut pembagian atau pemecahan atas bagiannya dalam persatuan harta kekayaan sebelum persatuan itu bubar. Hal demikian berbeda dengan dengan milik bersama bebas (vrije mede eigendom). Dalam milik bersama bebas, misalnya beberapa orang secara bersama-sama membeli sebidang tanah. Maka dalam hal ini masing-masing pembeli memperoleh bagian atas tanah tersebut, atau menuntut di depan hakim supaya tanah dijual dan ia mendapatkan bagiannya.

Dengan demikian ketika perkawinan putus, baru bisa dilakukan pembagian harta kekayaan perkawinan. Dalam kehidupan di masyarakat bentuk perkawinan pada umumnya adalah monogam, tetapi juga ada perkawinan lebih dari satu kali yang disebut perkawinan serial. Tentu saja cara pembagian 
harta kekayaan perkawinan antara perkawinan monogam dengan perkawinan serial berbeda. Cara pembagian yang terakhir tentu lebih kompleks dari yang pertama, karena terkait dengan keberadaan anak-anak perkawinan pertama yang harus mendapatkan perlindungan hukum. Selain itu, dengan fakta keragaman sistem hukum harta kekayaan perkawinan, pembagian harta kekayaan perkawinan dalam perkawinan serial juga didasarkan pada para pihaknya tunduk pada hukum apa.

Dalam UUP tidak secara tegas mengatur pembagian harta kekayaan perkawinan dalam perkawinan kedua. Namun apabila mencermati ketentuan yang terdapat dalam Pasal 65 ayat (1) huruf b UUP yang menyatakan, "isteri yang kedua dan seterusnya tidak mempunyai hak atas harta bersama yang telah ada sebelum perkawinan dengan isteri kedua atau berikutnya itu terjadi”. Selanjutnya dalam huruf c dinyatakan, "semua isteri mempunyai hak yang sama atas harta bersama yang terjadi sejak perkawinan masing-masing”. Dapat diambil kesimpulan bahwa hakikat pasal tersebut bisa digunakan untuk penyelesaian pembagian harta kekayaan perkawinan baik atas dasar perkawinan serial maupun atas dasar poligami.

Ketentuan tersebut menegaskan adanya beberapa asas, yakni pertama, dalam perkawinan serial ataupun poligami terbentuk beberapa paket harta bersama. kedua, terwujudnya harta bersama terhitung mulai tanggal perkawinan dilangsungkan. Ketiga, masing-masing harta bersama tersebut terpisah dan berdiri sendiri-sendiri. (Manaf, 2006)

Ada beberapa yurisprudensi yang terkait dengan hal di atas, yakni : Putusan MA No. 248 K/Sip/1958 tanggal 10 September 1958, antara lain menegaskan bahwa bilamana seorang laki-laki kawin dengan lebih dari seorang perempuan, sedangkan ada pula lebih dari satu gono gini, maka gono gini itu dipisahkan. Kemudian Putusan MA No. 3581 K/Pdt/1989 tanggal 2 Februari 1995, yang menyatakan: bahwa barang yang diperoleh dari perkawinan isteri pertama yang telah wafat, kemudian dibawa ke dalam perkawinan kedua, maka barang tersebut adalah harta bawaan, bukan harta bersama dengan isteri kedua. Selanjutnya, Putusan MA No. 343 K/AG/1995 tanggal 30 Oktober 1996, yang menyatakan : karena uang yang digunakan untuk membeli tanah dan rumah adalah milik isteri yang diperolehnya dari pembagian harta bersama dengan bekas suaminya terdahulu, maka tanah dan rumah tersebut adalah milik isteri, bukan sebagai harta bersama dengan suaminya yang kedua. (Manaf, 2006)

Konsep penyelesaian sengketa harta kekayaan perkawinan dalam perkawinan kedua dan seterunya sebagaimana di atas, berbeda dengan apa yang diatur dalam KUH.Perdata. Menurut ketentuan 
KUH.Perdata, pada dasarnya hukum harta kekayaan dalam perkawinan kedua sama dengan harta kekayaan pada perkawinan pertama. Hal tersebut sebagaimana dinyatakan dalam Pasal 180 KUH.Perdata, “dalam perkawinan untuk kedua kali dan selanjutnya berlakulah demi hukum suatu persatuan harta kekayaan bulat antara suami dan isteri, sekedar mengenai itu dengan perjanjian kawin tidak diadakan ketentuan lain. Ketentuan Pasal 180 KUH.Perdata tersebut senafas dengan ketentuan Pasal 119 KUH.Perdata, yang mengatur ketentuan harta kekayaan perkawinan dalam perkawinan pertama.

Pembuat undang-undang tidak menghendaki, bahwa suami atau isteri kedua karena perkawinan itu memperoleh keuntungan terlalu banyak, sehingga merugikan anak-anak atau keturunan dari perkawinan pertama. Agar supaya anak-anak dari perkawinan pertama tidak dirugikan terlalu banyak pembuat undang-undang membatasi keuntungan yang mungkin diperoleh si isteri atau sisuami kedua. Untuk itu undang-undang memberikan batasan yang diatur dalam empat pasal, yakni :

1. Pasal 181 dalam hal ada persatuan harta kekayaan

2. Pasal 182 dalam hal ada perjanjian kawin.

3. Pasal 852a dalam hal warisan tanpa testamen.
4. Pasal 902 dalam hal diberikan keuntungan-keuntungan dengan testamen.

Dalam hal keempat pasal tersebut, keuntungan yang mungkin diterima oleh suami/isteri dalam perkawinan kedua dan seterusnya dibatasi oleh dua hal, yakni :

1. Tidak boleh labih besar dari bagian terkecil yang diterima anak atau keturunannya dari perkawinan pertama.

2. Tidak boleh lebih besar dari $1 / 4$ harta suami/isteri yang kawin berulang tersebut.

Selanjutnya ditentukan bahwa keuntungan yang mungkin diperoleh karena keempat sebab tersebut di atas bersama-sama tidak boleh melebihi kedua batasan tersebut. Ketentuan-ketentuan ini disebut Lex Hac Edictali.

Dalam hal seseorang kawin untuk kedua kalinya dengan persatuan bulat dan dari perkawinan pertama ada anak, kemudian perkawinan putus karena kematian dan tidak ada testamen, maka suami atau isteri yang hidup terlama dalam mendapatkan hak atas harta peninggalan simati (pewaris) diatur dalam Pasal 181 dan Pasal 852a KUH.Perdata. Kedua pasal tersebut intinya membatasi bagian yang diterima suami atau isteri dalam perkawinan kedua, yakni bagiannya tidak boleh melebihi bagian terkecil anak, dan tidak boleh lebih besar dari sepermpat harta peninggalan. 
Pembagian harta kekayaan apabila ada suami atau isteri dalam perkawinan kedua dapat terjadi dalam hal-hal sebagai berikut :

1. Pembagian harta kekayaan dalam hal tidak ada persatuan harta;

2. Pembagian harta kekayaan dalam hal ada harta persatuan;

3. Pembagian harta kekayaan dalam hal ada harta persatuan dan keuntungan;

4. Pembagian harta kekayaan dalam hal ada harta persatuan dan kerugian;

5. Pembagian harta kekayaan dalam hal ada harta persatuan dan ada anak luar kawin yang diakui.

Dalam hal perkawinan kedua dilakukan dengan perjanjian kawin, yang berisi pemisahan harta, maka di antara suami isteri tersebut tidak ada persatuan yang harus dibagi, karena yang ada adalah harta pribadi masing-masing. Namun demikian, adanya perjanjian kawin yang berisi pemisahan harta perkawinan tersebut, tidak menghilangkan kedudukan suami stau isteri tersebut sebagai ahli waris. Oleh karena itu, suami atau isteri yang melangsungkan perkawinan dengan perjanjian kawin, akan tetap memperoleh haknya sebagai ahli waris manakala suami stau isterinya meninggal dunia. Dalam hal demikian, apabila menyangkut perkawinan kedua, maka bagian suami atau isteri yang hidup terlama dibatasi oleh kedua batasan tadi.

Dalam hal perkawinan kedua dengan persatuan bulat, maka penyelesain pembagian harta kekayaannya harus dicari "manfaat". Manfaat suami atau isteri yang hidup terlama adalah akibat dari kedudukan suami atau isteri yang hidup terlama tersebut sebagai ahli waris sekaligus berhak atas setengah harta warisan apabila perkawinan mereka dulu dilangsungkan tanpa didahului dengan perjanjian kawin. (Amanat, 2000)

\section{Simpulan}

Berdasarkan hasil dan pembahasan dalam artikel ini, penulis dapat menarik kesimpulan sebagai berikut:

1. Dalam keragaman aturan hukum harta kekayaan perkawinan di Indonesia, ditemukan kesamaan dalam memaknai dan melakukan pembagian harta kekayaan perkawinan. Kesamaan makna terkait dengan semua harta kekayaan yang diperoleh selama perkawinan di luar harta warisan dan hibah. Terhadap harta tersebut merupakan harta bersama suami istri dan ketika perkawinan putus, maka dilakukan pembagian yang sama bagian antara suami istri tersebut.

2. Dalam penyelesaian pembagian harta kekayaan dalam perkawinan labih dari satu atau serial, berpedoman pada asas bahwa dalam perkawinan lebih dari satu atau serial terbentuk masingmasing kelompok harta perkawinan yang terpisah dan berdiri sendirisendiri. Masing-masing kelompok 
harta perkawinan tersebut merupakan hak ahli waris dari perkawinan tersebut, sehingga ada perbedaan jumlah yang diterima masing-masing ahli waris sesuai dengan besarnya kelompok harta yang tercipta dalam perkawinan tersebut. Sedangkan menurut KUH.Perdata, terdapat pembatasan yang diterima isteri atau suami dalam perkawinan kedua. Keuntungan yang mungkin diterima oleh suami/isteri dalam perkawinan kedua dan seterusnya dibatasi oleh dua hal : Tidak boleh labih besar dari bagian terkecil yang diterima anak atau keturunannya dari perkawinan pertama, dan tidak boleh lebih besar dari 1/4 harta suami/isteri yang kawin berulang tersebut, sedangkan untuk bagian anak-anak baik dari perkawinan pertama atau kedua bagiannya sama.

Selanjutnya penulis dapat memberikan saran bahwa sampai saat ini, penyelesaian sengketa harta kekayaan perkawinan baik dalam perkawinan monogam maupun dalam perkawinan serial masih terdapat pluralitas aturan. Hal tersebut seringkali menimbulkan inkonsistensi dalam menerapkan aturan yang membawa akibat pada adanya ketidakadilan bagi para pihak yang bersengketa apabila salah dalam menerapkan hukum. Untuk itu perlu segera diatur ketentuan harta kekayaan perkawinan dalam peraturan pelaksanaan sebagai langkah awal sebelum membenahi ketentuan tersebut dalam aturan yang lebih rinci dalam undang-undang.

\section{DAFTAR PUSTAKA}

Amanat, A. (2000). Membagi Warisan Berdasarkan Pasal-Pasal BW. Jakarta: Rajawali Press.

Anshori, A. G. (2006). Filsafat Hukum. Yogyakarta: Gadjah Mada University Press.

de Vaus, D., Gray, M., Qu, L., \& Stanton, D. (2014). The Economic Consequences of Divorce in Australia. International Journal of Law, Policy and the Family, 28(1), 26-47. http://doi.org/10.1093/lawfam/ebt014 Fafchamps, M., \& Quisumbing, A. (2005). Assets at marriage in rural Ethiopia. Journal of Development Economics, $77(1)$,

http://doi.org/10.1016/j.jdeveco.2004. 02.003

Guba \& Lincoln. (2009). Berbagai Paradigma yang Bersaing dalam Penelitian Kualitatif. In Hand Book Of Qualitative Research. Yogyakarta: Pustaka Pelajar.

Harahap, M. Y. (1997). Kedudukan Kewenangan dan Acara Peradilan 
Agama. Pustaka Kartin.

Judiasih, S. D. (2018). Model Perjanjian Kawin Yang Dibuat Setelah Perkawinan Berlangsung Pasca Berlakunya Putusan Mahkamah Konstitusi Nomor 69/Puu-Xiii/20151. Masalah-Masalah Hukum, 47(3), 253$267 . \quad$ Retrieved from https://ejournal.undip.ac.id/index.php/ mmh/article/view/17297/14072\%0D

Manaf, A. (2006). Aplikasi Asas Equalitas Hak Dan Kedudukan Suami Isteri Dalam Penjaminan Harta Bersama Pada Putusan Mahkamah Agung. Bandung: Mandar Maju.

Manan, A. (2006). Aspek Aspek Pengubah Hukum. Jakarta: Kencana.

Pudjirahayu, E. W. (2005). Pranata Hukum Sebuah Telaah Sosiologis. Semarang: Suryandaru Utama.

Rifai, A. (2010). Penemuan Hukum Oleh Hakim Dalam Perspektif Hukum Progresif. Jakarta: Sinar Grafika.

Riyanto, R. B. (2009). Kebebasan Hakim. Semarang: Badan Penerbit Universitas Diponegoro.

Satrio, J. (1991). Hukum Harta Perkawinan, Bandung. Bandung: Citra Aditya Bhakti.

Sirajudin. (2015). KONSTRUKSI HUKUM KELUARGA ISLAM DI INDONESIA : Analisis terhadap Undang-Undang RI No . 1 Tahun 1974 tentang Perkawinan dan KHI. Istinbath
Jurnal Hukum Islam, 14(2), 159-175.

Tanya, B. L. (2011). Politik Hukum: Agenda kepentingan bersama. Yogyakarta: Genta Publishing. 